\title{
Science and Technology for Alen-Alen Entrepreneur Communities
}

\author{
Hotnida Sinaga $^{1 *}$, Linda Masniary Lubis ${ }^{1}$, Siti Kadijah Nasution ${ }^{2}$ \\ ${ }^{1)}$ Department of Food Science and Technology, Faculty of Agriclture, University of Sumatera Utara \\ ${ }^{2)}$ Department of Agribusiness, Faculty of Agriculture, University of Sumatera Utara
}

\begin{abstract}
This community service activity was intended to assist entrepreneurs engaged in the production of alen-alen, a product made from cassava. There are some problems encountered in the production process, such as washing raw materials manually, work safety during the production practice, products that are not in accordance with standard hygiene and sanitation and packaging process that has not been designed properly. The entrepreneurs want to increase production but the equipment and processing machinery are very limited. To overcome this problem, several methods can be performed by the academics, such as facilitating them with appropriate tools that meet the needs in the field. A cassava washer unit and specific boiler tools to avoid hot steam when taking the material were offered. In addition, entrepreneurs were trained in hygiene and sanitation in alen-alen making, educated for packaging technology quality, raw material selection and the use of food coloring, formulating variations for alen-alen manufacture, as well as financial bookkeeping training. The implementation of these activities is expected to generate shorter production process time leading to further increase in the production, income and welfare of the entrepreneurs.
\end{abstract}

Keywords: Alen-alen, Food Snacks, Cassava, Industrial Entrepreneurs

Abstrak. Kegiatan pengabdian masyarakat ini ditujukan untuk membantu para pengusaha kecil yang bergerak di bidang produksi alen-alen ubi kayu. Mereka memiliki masalah dalam proses produksi, diantaranya mencuci bahan baku secara manual, keselamatan kerja selama proses produksi dan produk yang belum sesuai dengan standart hygiene dan sanitasi maupun proses pengemasan yang belum didesain dengan baik. Para pengusaha ingin menambah produksi tapi alat dan mesin proses pengolahan terbatas. Untuk mengatasi masalah ini maka dilakukan beberapa metode yang mampu dikerjakan oleh para akademisi pelaksana pengabdian ini yaitu: membantu memberikan alat yang sesuai dengan kebutuhan di lapangan, antara lain mesin pencuci ubi kayu dan dandang untuk menghindari uap panas ketika 
pengambilan bahan. Sebagai tambahan, para pengusaha diberikan pelatihan untuk hygiene dan sanitasi dalam pembuatan alen-alen, pelatihan untuk teknologi pengemasan yang bermutu, pelatihan dalam pemilihan bahan baku yang bermutu dan variasi produk untuk pembuatan alen-alen, pelatihan dalam penggunaan warna yang bermutu dan layak untuk pangan, pelatihan pembukuan keuangan. Dengan pelaksanaan pengabdian ini diharapkan waktu proses produksi akan semakin singkat sehingga dapat lebih meningkatkan produksi, penghasilan dan kesejahteraan para pengusaha kecil.

Kata Kunci: Alen-alen, Makanan Ringan, Ubi Kayu, Pengusaha

Received 22 October 2017 | Revised 10 December 2017 | Accepted 9 March 2018

\section{Introduction}

One of the areas in North Sumatera province that has many small entrepreneurs in the field of food products is Binjai city. There are 2 partners on this community service, both of them are cassava alen-alen entrepreneurs who are still can be grouped as small scale entrepreneurs, which is located at Cengkeh Turi Village, North Binjai District.

The first entrepreneur uses cassava raw materials for the manufacture of alen-alen, purchased from cassava suppliers (intermediary traders) from Binjai and the surrounding areas. The production capacity was $300 \mathrm{~kg}$ of cassava / day which eventually decrease to $100 \mathrm{~kg}$ alen-alen / day, with 8 staff members and production time at 08.00 - 15.00 Western Indonesian Time (WIB) from Monday to Saturday. The initial products are uncooked alen-alen that need to undergo further processing, so the shelf life is quite short. The price of the uncooked alan-alen is around $\mathrm{Rp} 6.000,-/ \mathrm{kg}$, resulting in total production of Rp 600.000,-/day. With an average work of only 5 days in a week, the total sale reaches around Rp.13.000.000,-/month. The target areas for marketing are Binjai, Medan, Stabat and Tanjung Pura.

The equipment used for the production process is very simple, including cassava steamers, cassava grinding machine and getuk moulding machine. The initial work to peel and wash the cassava is done manually, with time consumes about 3 hours. Then, the cassava will be steamed, seasoned and grounded with an additional working time of 3 hours. The moulding process starts since the cassava begins to be spiced, so the workers can share the task for the continuation of production. As the moulding is done manually, there is a wide variation amongst the alen-alen production. These variations in turn will also affect product quality, especially while the alen-alen undertake further processing. Therefore, the entrepreneurs want to ease their work by asking help from the academics to facilitate simpler production. The academics staff offered the use of equipment such a cassava machine, alen-alen moulding machine, alen-alen container and drying oven, along with sharing knowledge to produce better quality product. 
The second entrepreneur founded alen-alen manufacturing business since 1990. Similar to the previous entrepreneur, the second farmer also uses cassava and spices that are available from Binjai and surrounding areas. With a total number of 7 workers and 9 hour working time (Monday to Saturday), $350 \mathrm{~kg}$ raw material cassava yield $120 \mathrm{~kg}$ alen-alen/day. By having total income of Rp. 720.000,-/day, the total retailing is about Rp.16.000.000,-/month. The equipment's used are cassava steamers, cassava grinding machines, and getuk moulding machines. To simplify the production work, this small entrepreneur hopes to get help in the form of a sweet washing machine, alen-alen printing machine, alen-alen container and drying oven.

In addition, the two entrepreneurs are still not so concerned with the good production practices (GPP), including product hygiene and sanitation, packaging, raw material selection, the addition of food coloring and other problems that are closely related to the quality of food and human health that consume them. The production process is still using a very simple facility, for examples: not wearing gloves, sun drying method and the unclean place for the drying process. Moulded products are dried in the yard of the production house, which is very close to public road facilities. This can cause ash, smoke or pollution from passing vehicles to be attached to the drying material, especially if the material is still wet.

In comparison with this alen-alen is a typical alen-alen produced by entrepreneurs from Trenggalek, East Java. They sell $70 \mathrm{~kg}$ of fried alen-alen per day, but during Eid celebration, the demand for alen-alen can rise up to $150 \%$. Moreover, the demand for alen-alen crackers has recently increased, due to the large demand from traders. Another alternative to increase production capacity, is to add working hours of the workers. Usually the process of making alen-alen snacks can be completed in half day, however, when demand increases they have to work until full day. Occasionally, woman workers work from morning to the noon period, while man workers continue to fry the remaining alen-alen until all the process completed.

Although the market demand is actually very high, but generally the small entrepreneurs can not fulfill the market because of raw material and labor limitations. The fried alen-alen are sold at Rp 20,000,- per kilogram for the retail segment directly to consumers. The price for distributors and intermediate traders are cheaper, $\mathrm{Rp} 16.000 .000$,- per kilogram to maintain healthy competition at retail level.

Based on the review to the field areas, it is necessary to provide assistance to the small entrepreneurs, so that they can develop their products for the better quality and become specific/ traditional food from Binjai area. The contribution of science to the entrepreneurs is expected to make them more enthusiasm to improve the quality of products and also their income in the future. 


\section{Method}

Training implementation methods used in this community service to solve partners' problems are:

- Preparation of cassava washing machine and cooking tools, followed by training on how to use the tools provided

- Training on Hygiene and Sanitation in the manufacture of alen-alen

- Training in selection of quality raw materials and product variety for making alen-alen

- Training in the use of qualified and feasible food coloring

- Training on financial Bookkeeping

During the training, there are direct practices, discussion and question and answer with the instructors.In the implementation of this activity participation of the partners is required, especially in the form of their willingness to be trained and providing time for the training. In addition, small entrepreneurs are expected to prepare training venues, to accomplish all the results of the training that has been held. To find out the positive results of the implemented program, the small entrepreneurs must be willing to be evaluated every 3 months.

\section{Results and Discussion}

Based on the identification of problems in the field areas, the academic team discusses the solutions offered to solve the problems of small entrepreneurs. After a direct visit to the field, academics identify problems found in the field, which are: the necessity to provide a cassava washer, a special cooking tools design, so that the workers are not exposed to the direct steam and improving the quality of the generated alen-alen.

Before starting the activity, the team holds a meeting for consolidation in conducting the training. The result of this meeting was followed up by holding a consultation with small-scale business of alan-alen, to discuss and design the tools and machines in accordance with the needs in the field (Figure $1(\mathrm{~A})$ ).
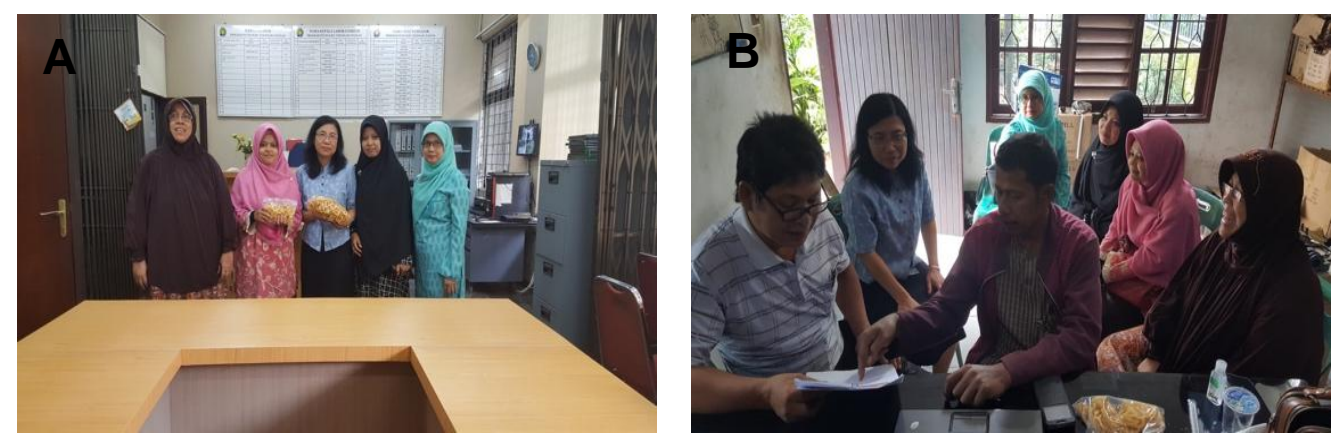

Figure 1. Initial discussion (A) and the design of a cassava machine (B) 
Based on the combination of application of science and technology and the entrepreneur's experience in the field, it is designed a tool that is expected to facilitate and ease the work (Figure 1 (B)). A cassava washing machine was constructed with a capacity of $100 \mathrm{~kg}$ cassava with a washing time of about 15-30 minutes (Figure 2).

To facilitate the removal of cassava from the cage after boiling, it is designed a tool that can be incorporated into the steamer. Cassava will be put into the cage, and lifted with the help of pulley, so that the worker did not directly exposed to the steaming smoke while taking the cassava from the boiled tool (Figure 3).

Another problem is, the two entrepreneurs are still selling raw alen-alen and still require further processing before consumption. This causes the low price of their products, while the fried products can be sold at $\mathrm{Rp} 12.000,-/ \mathrm{kg}$ or double of raw products' price. The trading of these crude alen-alen would be beneficial for intermediary traders, because they can have similar benefit only by frying these raw products. They have more profit than the small entrepreneurs who started their production since peeling and washing cassava. The entrepreneurs do not have enough time to process further, because the production of raw alen-alen itself already takes about 8-9 hours. Therefore, it is expected that the provision of aid equipment or machines that can facilitate the work of entrepreneurs can increase their income, because the production time will be shorter and the entrepreneur could further process the food before it is marketed.
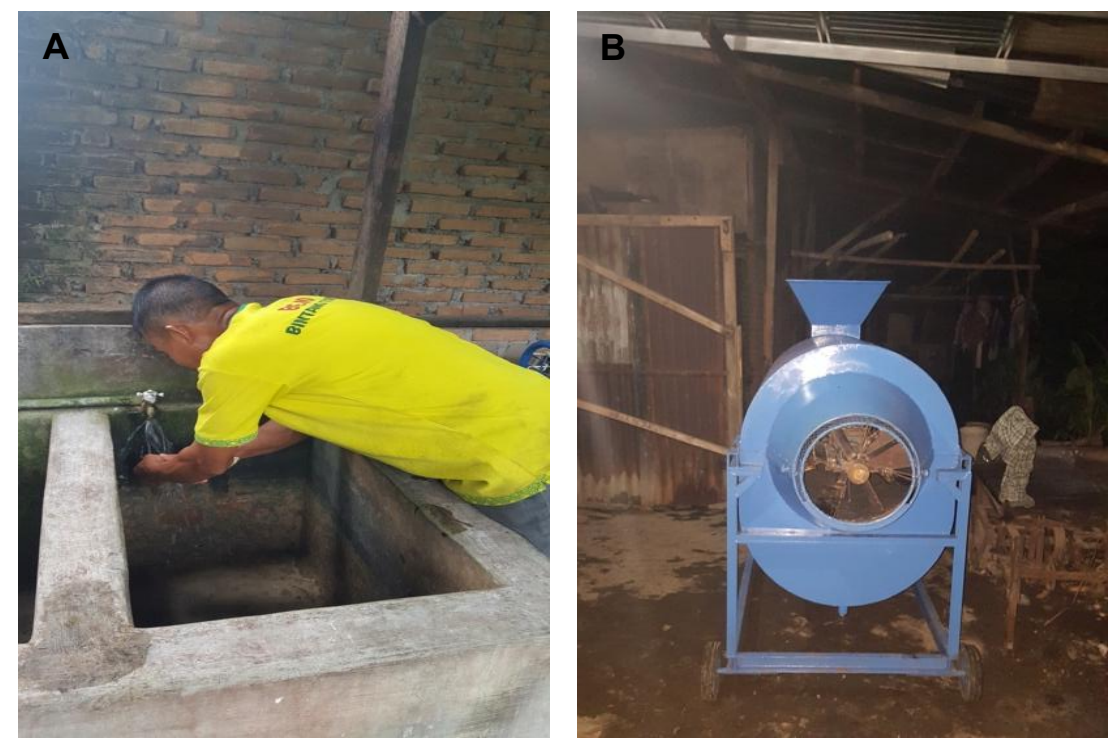

Figure 2. Manual washing of cassava (A) and cassava washing machine (B) 

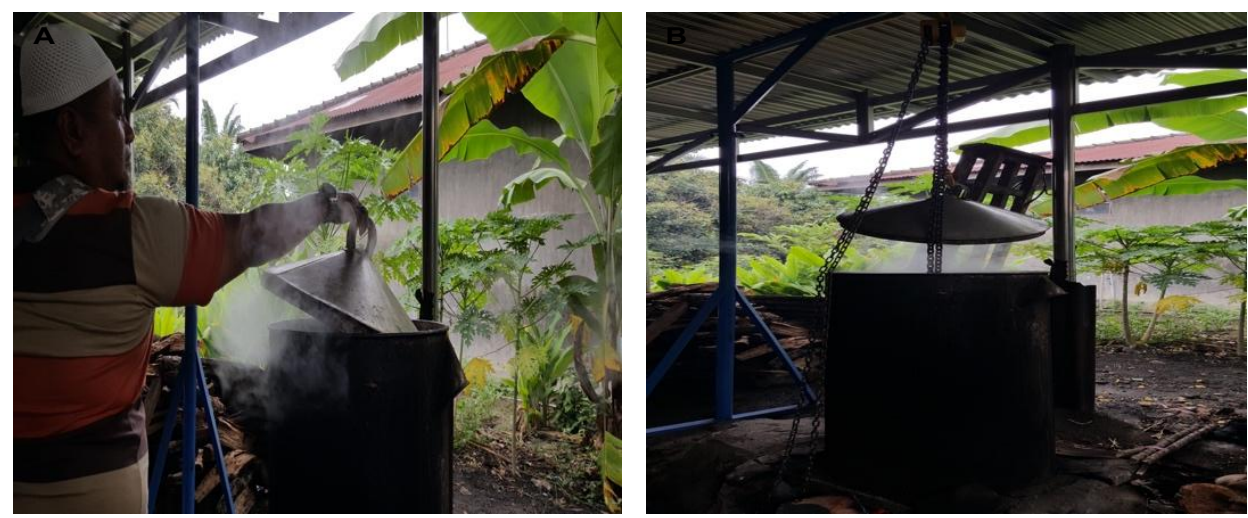

Figure 3. The steam which produces hot smoke (A) and the enclosure using a pulley (B)

Following the delivering of aid tools, training on sanitary hygiene and packaging technology are carried out. The small entrepreneurs are advised to not sell the alen-alen in raw form, but having fried and packaged before marketing. The packaged products can later be accompanied by the manufacture of good brands and labels on the packaging, to increase the added value of the product. This implementation is expected to increase more income and profit of entrepreneurs. In the early stages, the academics will assist in marketing the products that consumers can directly consume (Figure 4).
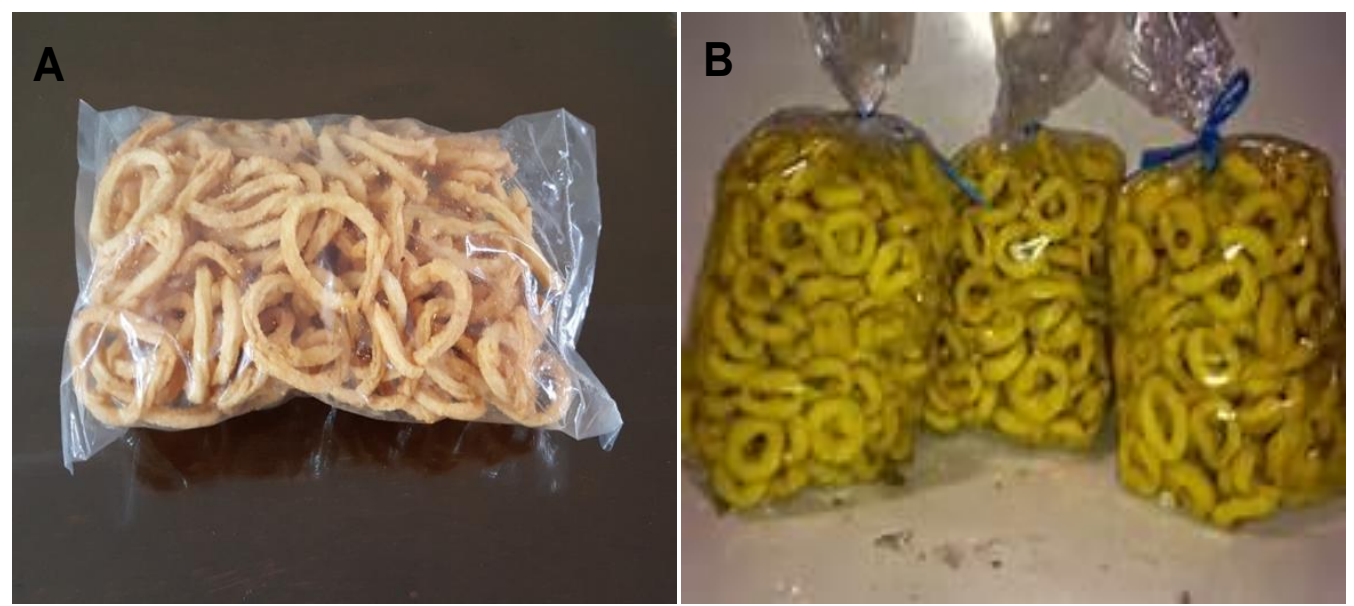

Figure 4. Typical alen-alen packaging in Binjai (A) and in Trenggalek (B)

This community service is planned to be continued by implementation of product variation in flavour, taste, sweet, sour or other flavour that might be possible to add the alen-alen value.

In terms of business management, the two entrepreneurs are still doing it traditionally, and have not done the bookkeeping of their need and spending money. Therefore, in addition to increased production, the academic team also tries to assist entrepreneurs in their bookkeeping production. It is expected that all community service activities will have a positive impact for small entrepreneurs. 


\section{Conclusion}

The academics can help the community to overcome the problems they face by design and manufacture of equipment as needed, such as cassava washing machines and cooking tools equipped with pulleys for the safety of workers during the production process, and provide training to improve product quality so as to increase the income of small entrepreneurs

\section{Acknowledgments}

The authors thanked the Directorate of Research and Community Service, Directorate General for Research and Development, Ministry of Research, Technology and Higher Education who have funded this activity in accordance with the Letter of Funding Agreement for the Implementation of Community Service Program No. 003 / SP2H / PPM / DRPM / IV / 2017 dated April 20, 2017.

\section{References}

[1] Grace, M.R. 2011.Cassava Processing, FAO Plant Production and Protection Series No. 3, Rome, Italy.

[2] Hardi, V. 2013. Makanan khas Trenggalek, Alen-alen. http://trenggalekkuliner.blogspot.co.id/2013/03/alen-alen.html. Accessed on 1 October 2017

[3] Howeler, R.H. 2012. The Cassava Handbook, A Reference Manual based on the Asian Regional Cassava Training Course, Centro Internacional de Agricultura Tropical (CIAT), the Department of Agriculture (DOA), The Thai Tapioca Development Institute (TTDI), Thailand.

[4] Mujito. 2011. Jajanan khas Trenggalek. Alen-alen rasa pedas. http://jajanankhastrenggalek.blogspot.co.id/ . Accessed on 1 October 2017

[5] Sujarwoko. 2016. Permintaan jajanan alen-alen Trenggalek meningkat. http://www.antarajatim.com/berita/180344/permintaan-jajanan-alen-alentrenggalek-meningkat. Accessed on 1 October 2017 